\title{
Separation Study of Silver(I) Ion through a Bulk Liquid Membrane Containing Meloxicam
}

\author{
Khalil Farhadi, ${ }^{* a}$ Shahriyar Bahar ${ }^{a}$ and Ramin Maleki ${ }^{a, b}$ \\ ${ }^{a}$ Department of Chemistry, Faculty of Science, Urmia University, Urmia, Iran \\ ${ }^{b}$ Food and Chemical Analysis Research Lab., Jahad-e-Daneshgahi, Urmia, Iran
}

\begin{abstract}
Estudou-se o transporte ativo de íons $\mathrm{Ag}^{+}$através de uma membrana líquida de clorofórmio contendo meloxicam. Avaliaram-se diferentes condições experimentais para aumentar a seletividade, sensibilidade e a velocidade de transporte, como por exemplo, efeito da concentração de meloxicam na membrana de clorofórmio, $\mathrm{pH}$ das fases doadoras e receptoras, tipos e concentrações de agentes removedores. Na presença de tiocianato, um agente removedor eficiente na fase receptora, a quantidade de íons $\mathrm{Ag}^{+}$transportados através da membrana líquida foi de $97,8 \pm 1,2 \%$ em 120 min. A seletividade e eficiência do transporte dos íons $\mathrm{Ag}^{+}$a partir de soluções aquosas contendo outros cátions, como $\mathrm{Co}^{2+}, \mathrm{Cr}^{3+}, \mathrm{Ni}^{2+}, \mathrm{Cd}^{2+}, \mathrm{Mn}^{2+}, \mathrm{Cu}^{2+}, \mathrm{Pb}^{2+}, \mathrm{Ca}^{2+}$, $\mathrm{Mg}^{2+}$ e $\mathrm{Zn}^{2+}$ foram investigadas. Com exceção dos íons $\mathrm{Cr}^{3+}$ e $\mathrm{Pb}^{2+}$, os cátions não interferiram no transporte dos íons $\mathrm{Ag}^{+}$, mesmo em razões molares $\mathrm{M}^{\mathrm{n}} / \mathrm{Ag}^{+}$da ordem de 500. O efeito interferente desses dois cátions foi minimizado na presença de EDTA em pH 6.
\end{abstract}

The uphill transport of $\mathrm{Ag}^{+}$through a chloroform bulk liquid membrane containing meloxicam as an ion carrier was studied. Different experimental conditions for the increasing selectivity, sensitivity and kinetics of transport, e. g., the effect of meloxicam concentration in the chloroform membrane phase, $\mathrm{pH}$ of donors and acceptor phases, types and concentration of various stripping agents were examined. In the presence of thiocyanate as a suitable stripping agent in the acceptor phase, the amount of silver transported across the liquid membrane after $120 \mathrm{~min}$ was $97.8 \pm 1.2 \%$. The selectivity and efficiency of $\mathrm{Ag}^{+}$transport from the aqueous solution containing other cations, such as: $\mathrm{Co}^{2+}, \mathrm{Cr}^{3+}, \mathrm{Ni}^{2+}, \mathrm{Cd}^{2+}, \mathrm{Mn}^{2+}, \mathrm{Cu}^{2+}, \mathrm{Pb}^{2+}, \mathrm{Ca}^{2+}, \mathrm{Mg}^{2+}$ and $\mathrm{Zn}^{2+}$ were investigated. Except $\mathrm{Cr}^{3+}$ and $\mathrm{Pb}^{2+}$ ions, none of the cations used interfere the silver transport, even at a $\mathrm{M}^{\mathrm{n}+} / \mathrm{Ag}^{+}$molar ratio of 500. The interfering effect of the two mentioned cations was diminished in the presence of EDTA at $\mathrm{pH} 6$.

Keywords: liquid membrane, silver transport, meloxicam

\section{Introduction}

Usually in many analytical methods the performing of a separation step is necessary during the analysis. Among various separation methods (ion exchange, solvent extraction, selective chemical precipitation etc.) one interesting approach is based on the recognition, binding and release of specific solutes carried out by facilitated transport membranes, i.e. organic liquid in contact with two separated aqueous phases working under chemical gradient as the driving force. This technique has been widely used for carrier metal ion separations ${ }^{1-4}$ and, to a lesser degree, for organic compounds separation. ${ }^{5,6}$

*e-mail: kh.farhadi@mail.urmia.ac.ir or khfarhadi@yahoo.com
Silver as a high valuable metal, has a wide range of industrial applications (photographic processing, electrochemical plating etc.). On the other hand, it is toxic and rejected, consequently strongly regulated. Liquidliquid extraction and separation of silver in the presence of classical ${ }^{7-9}$ and macrocyclic ligands ${ }^{10-12}$ is frequently reported in the literature. However, a serious limitation in traditional solvent extraction processes is that a large amount of high purity solvents (and carriers) is required, especially when processing dilute solutions. Additional concern is the disposal of the solvents used, which creates a severe environmental problem. Therefore, during the past decade, there have been some studies on $\mathrm{Ag}^{+}$-selective membrane transport using various carriers. ${ }^{4,13-23}$ Nearly, in most of these transports, selective carriers for silver as a soft metal ion are sulphur-containing macromolecules (both cyclic and open-chain sulphur 
donor), aza thiacrown ethers derivatives with mixed $\mathrm{S}$ and $\mathrm{N}$ donor sites and macrocyclic reagents possessing $\mathrm{S}, \mathrm{N}$, $\mathrm{O}$ donors. ${ }^{24,25}$ Since their use in commercial routes may seem prohibitive and expensive due to the complexity of their syntheses, therefore, in recent years, the introduction of simple complexants for the selective transport of silver ions is of increasing interest. ${ }^{23-25}$

We have recently studied the reaction between various drugs and metal cations in order to develop new separation and determination methods for cations or drugs. ${ }^{26-28}$ From the results obtained, we used thioridazine $\cdot \mathrm{HCl}$ as a suitable carrier for the uphill transport of $\mathrm{Pd}(\mathrm{II})^{26}$ and as efficient modifier in selective separation of palladium in solid-phase extraction techniques..$^{27,28}$ In the present work we initially studied the complexation reactions between meloxicam (MLC, a non-steroidal anti-inflammatory drug of the enolic acid class of oxicam derivatives containing mixed $\mathrm{N}, \mathrm{S}$ and $\mathrm{O}$ sets) and $\mathrm{Ag}(\mathrm{I})$ in water-methanol mixture by turbidimetric and FT-IR spectrophotometric methods. Then we employed MLC as an excellent specific ion carrier for the selective transport of $\mathrm{Ag}^{+}$ions through a bulk chloroform membrane. Therefore, the efficiency of MLC on the transport of silver ions at various conditions was studied. In the presence of thiocyanate as a suitable metal ion acceptor in the acceptor phase, a low concentration of MLC as $5 \times 10^{-4} \mathrm{~mol} \mathrm{~L}^{-1}$ was found to transport the silver ions quantitatively and selectively across the liquid membrane at a period of time $120 \mathrm{~min}$.

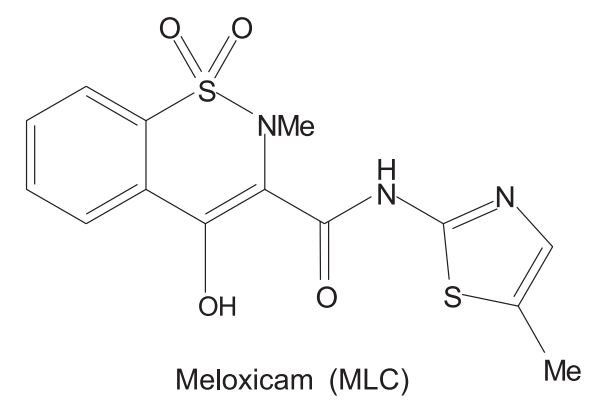

\section{Experimental}

\section{Reagents}

Reagent-grade chloroform (Merck) was used as the membrane organic solvent. All other chemicals used in this study were of the highest purity available from either Merck or Fluka chemical companies and used without further purification, except for vacuum drying over $\mathrm{P}_{2} \mathrm{O}_{5}$. Doubly distilled deionized water was used throughout.

\section{Apparatus}

A bulk-type liquid membrane cell was used in this study. ${ }^{29}$ The $\mathrm{pH}$ measurements were made with a digital WTW multilab 540 Ionalyzer (Germany) pH/ion meter using a combined glass electrode. The flame atomic absorption spectrophotometer used for the measurement of metal ion concentration in the aqueous phases was a Shimadzu AA-670 instrument. The atomic absorption measurements were made under the recommended conditions for each metal ion. A LKB model $4054 \mathrm{UV}$ vis recording spectrophotometer with $10 \mathrm{~mm}$ matched silica cells was used for turbidimetric measurements. The FT-IR spectra were recorded with a Nexus model 670 FT-IR spectrophotometer.

\section{Procedure}

All transport experiments were carried out at ambient temperature. A cylindrical glass cell $(4.0 \mathrm{~cm}$, i.d.) holding a glass tube $(2.0 \mathrm{~cm}$, i.d.), for separating the two aqueous phases was used (Figure 1). The inner aqueous phase (donor phase, A) contained silver nitrate ( $5 \mathrm{~mL}, 1 \times 10^{-4} \mathrm{~mol} \mathrm{~L}^{-1}$ ). The outer aqueous phase (acceptor phase, B) contained potassium thiocyanate (10 mL, $0.1 \mathrm{~mol} \mathrm{~L}^{-1}, \mathrm{pH}$ 7). The chloroform solution (membrane phase, C) containing $20 \mathrm{~mL}$ of $5 \times 10^{-4} \mathrm{~mol}$ $\mathrm{L}^{-1}$ MLC, lay below these aqueous phases and bridged them. The organic layer with a thickness of $1.6 \mathrm{~cm}$ was slowly stirred by Teflon-coated magnetic bar $(1.5 \mathrm{~cm}$ $\times 5 \mathrm{~mm}$ diameter). Determination of the metal ion concentration in both aqueous phases was carried out by flame atomic absorption spectrometry. Reproducibility was confirmed as $\pm 1.20 \%$ or better. A similar transport experiment was carried out in the absence of the carrier for reference. Detailed conditions are included in the tables and figures.

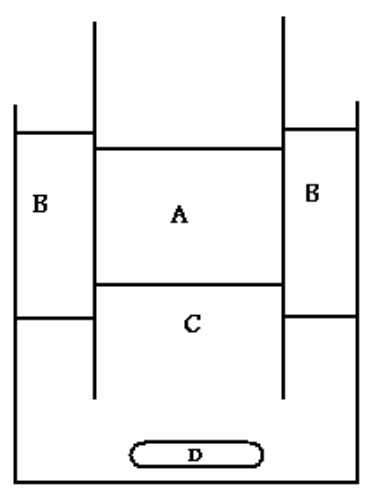

Figure 1. Representation of the bulk type liquid membrane cell used. (A) donor phase; (B) acceptor phase; (C) membrane phase; (D) magnetic stirrer. 


\section{Results and Discussion}

\section{Study of reaction between $M L C$ and $\mathrm{Ag}^{+}$}

In the continuation of our studies in complexation reactions between drugs and various cations, ${ }^{26-28}$ we have evaluated the possible reactions of MLC with some cations. Since MLC is insoluble in water, therefore, a solution of MLC in methanol was used for this purpose. Preliminary studies showed that while the solutions of various cations have no considerable interaction with MLC, an aqueous silver solution forms a stable yellow precipitate with MLC. Therefore, we initially studied the possible reaction between $\mathrm{Ag}^{+}$and MLC using turbidimetry and FT-IR techniques. The stoichiometric ratio of the reactants was determined using turbidimetric method at $520 \mathrm{~nm}$. A typical mole-ratio plot is shown in Figure 2. As it can be seen, a clear break in mole/ratio $\approx 1$ emphasizing the formation of a 1:1 molecular complex, according to the following reaction:

$\mathrm{MLC}^{-}+\mathrm{Ag}^{+} \rightleftharpoons \mathrm{Ag}-\mathrm{MLC}$

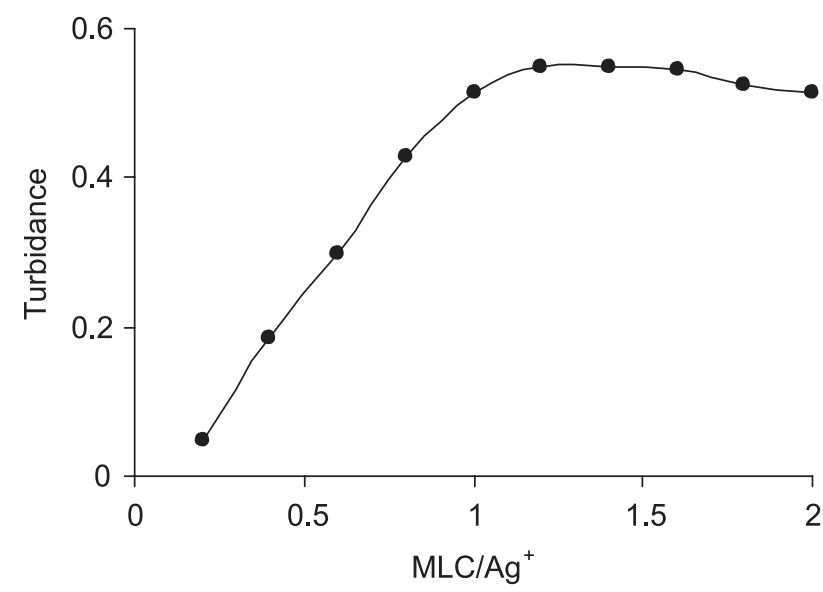

Figure 2. Mole ratio plat obtained from the titration of $0.1 \mathrm{~mL} \mathrm{Ag}+0.01$ $\mathrm{mol} \mathrm{L}-1+5 \mathrm{~mL} \mathrm{MeOH}+2 \mathrm{~mL} \mathrm{H}_{2} \mathrm{O}$ with MLC $2 \times 10^{-4} \mathrm{~mol} \mathrm{~L}^{-1}$.

The FT-IR spectra of the MLC (Figure 3a) and AgMLC complex (Figure $3 b$ ) are recorded in the solid state as $\mathrm{KBr}$ discs which illustrate the different bands arising from the functional groups in these compounds. The absorption in the 4000-2600 $\mathrm{cm}^{-1}$ ranges involves the bands of $-\mathrm{OH},-\mathrm{NH}$ as well as those of the $\mathrm{C}-\mathrm{H}$ phenyl and $\mathrm{C}-\mathrm{H}$ aliphatic. The spectrum of MLC contains a wide band at $3436 \mathrm{~cm}^{-1}$ which is a composite band showing stretching frequencies of $\mathrm{C}-\mathrm{H}$, strongly the $\mathrm{O}-\mathrm{H}$ stretching frequency and the $-\mathrm{NH}$ stretching frequency of secondary amide. This broadening is probably related to the presence of intramolecular hydrogen bonding in the structure of MLC. On the other hand, the stretching vibration band of

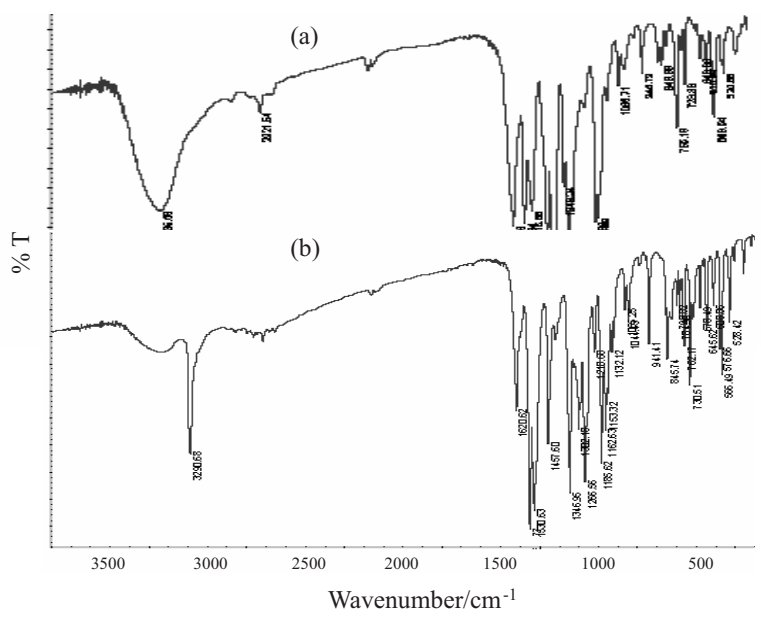

Figure 3. FT-IR spectrum of: a) MLC, b) the resulting precipitate of interaction between MLC and $\mathrm{Ag}+$ ions from methanol solution.

$\mathrm{C}=\mathrm{O}$ appears at $1610 \mathrm{~cm}^{-1}$ in MLC and changes to 1620 $\mathrm{cm}^{-1}$ after complexation. These results once again confirmed that the open conformer of MLC participates in complexation with $\mathrm{Ag}^{+}$, because a $10 \mathrm{~cm}^{-1}$ shift in frequency is probably resulted from the inductive effect of $-\mathrm{NH}$ group (after complexation) on the stretching vibration band of $\mathrm{C}=\mathrm{O}$. In addition, the appearance of new bands in MLC-Ag complex at $576 \mathrm{~cm}^{-1}$ and $496 \mathrm{~cm}^{-1}$ are expected belong to $\mathrm{M}-\mathrm{N}$ and $\mathrm{M}-\mathrm{O}$ bonds, respectively. Finally, the appearance of new bands in the $600-700 \mathrm{~cm}^{-1}$ region of complex spectrum which was assigned as $\gamma_{c-s}$ showing a direct coordination of $-\mathrm{S}$ : with $\mathrm{Ag}^{+}$ions. From these observations, it can be proposed a 1:1 complex between $\mathrm{Ag}^{+}$and MLC according to the following scheme.

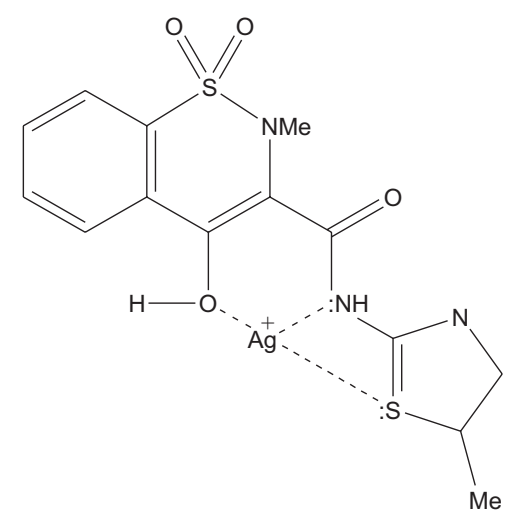

Scheme 1. Complex between MLC and $\mathrm{Ag}^{+}$ion.

Transport of $\mathrm{Ag}^{+}$ions across a bulk liquid membrane containing $M L C$

Selective reagents for binding of metal ions are of special importance to broad areas of analytical chemistry and separation science. Complexing agents with soft coordination sites like sulfur are known to generate a great 
affinity toward $\mathrm{d}^{10}$ transition metal ions such as $\mathrm{Ag}^{+}$. On the other hand, a ligand for use as a suitable ion-carrier in a liquid membrane system should have rapid exchange kinetics and should be sufficiently lipophilic to avoid leaching into the aqueous donor and acceptor phases. Since MLC is a chelating reagent that is insoluble in water and can form a fairly stable complex with $\mathrm{Ag}^{+}$ion in nonaqueous media (see previous section), we were interested in examining MLC as a potential ion-carrier for the selective and efficient transport of $\mathrm{Ag}^{+}$ion through a bulk type chloroform membrane.

The liquid membrane operated here is schematically illustrated in Figure 4. After the complexation of carrier with $\mathrm{Ag}^{+}$on the left side of the membrane and therefore releasing $\mathrm{H}^{+}$to the donor phase, the neutral complex formed diffused down its concentration gradient. On the right side of the membrane the metal ion is released into the acceptor phase containing large amount of $\mathrm{SCN}^{-}$via formation of a stable $\left[\mathrm{Ag}(\mathrm{SCN})_{2}\right]^{-}$complex ion. At this stage the carrier diffuses back across the membrane. The net result is the transport of silver ions from the aqueous donor phase to the aqueous acceptor phase across the bulk of the organic phase (the membrane). It should be noted that, the presence of lipophilic anions such as picrate and perchlorate in donor phase showed no improvement on the time and transport efficiency of silver ions. This result, once again, confirmed the formation of neutral complex between $\mathrm{Ag}^{+}$and $\mathrm{MLC}^{-}$in the interface of two aqueousorganic phases.

\section{Donor phase Membrane phase Acceptor phase}

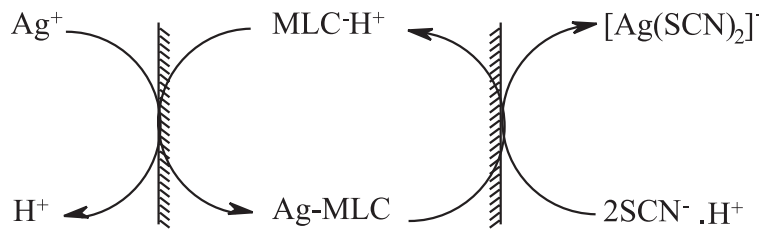

Figure 4. Liquid membrane system for transport of $\mathrm{Ag}^{+}$ions.

The proposed membrane system was first optimized with respect to the concentration of MLC by keeping the amount of one the constituent's constant and varying the concentration of the other one. The effect of the concentration of MLC in the membrane phase on the transport of silver was studied and the results are shown in Figure 5A. It is seen that the percentage of silver ion transported increases with increasing MLC in the membrane phase and, at $5 \times 10^{-4} \mathrm{~mol} \mathrm{~L}^{-1} \mathrm{MLC}$ is much more effective in the efficient transport of silver ions after $120 \mathrm{~min}$

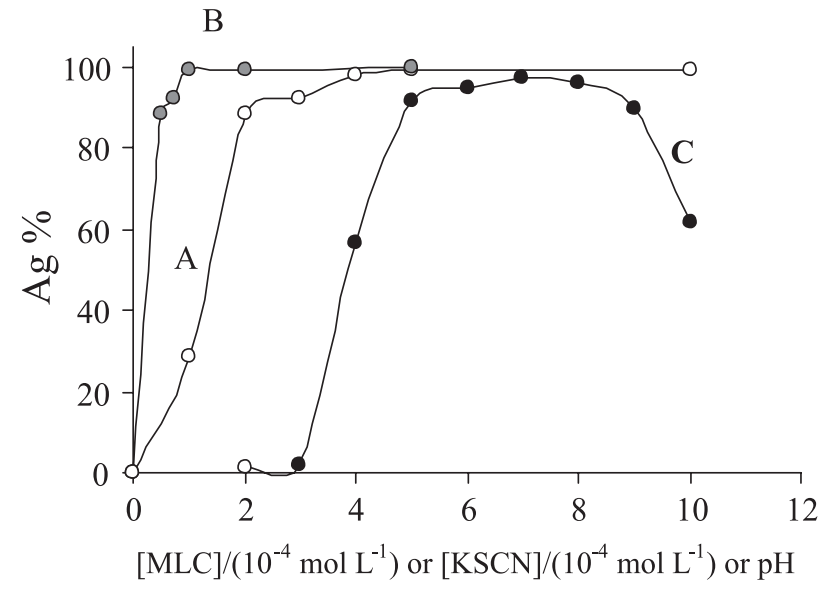

Figure 5. Effect of MLC concentration (A), KSCN concentration (B) and $\mathrm{pH}(\mathrm{C})$ on $\mathrm{Ag}^{+}$transport.

Permeability of the membrane system for $\mathrm{Ag}^{+}$ion with respect different stripping agents in the acceptor phase was investigated and the results are summarized in Table 1. As expected, it was found that the nature and composition of the ligand used as scavenger for the transported metal ion in the acceptor phase could have a significant effect on the efficiency and selectivity of silver transport. The use of $\mathrm{SCN}^{-}$ion as the stripping ligand in the acceptor phase caused a large enhancement in the efficiency and selectivity of $\mathrm{Ag}^{+}$ions, while the presence of other acceptor agents such as $\mathrm{S}_{2} \mathrm{O}_{3}{ }^{2-}\left(0.1-1 \mathrm{~mol} \mathrm{~L}^{-1}\right)$, $\mathrm{NH}_{3}\left(1 \mathrm{~mol} \mathrm{~L}^{-1}\right), \mathrm{SO}_{3}^{2-}\left(0.5 \mathrm{~mol} \mathrm{~L}^{-1}\right)$ and $\mathrm{I}^{-}\left(0.5 \mathrm{~mol} \mathrm{~L}^{-1}\right)$ resulted in a pronounced decrease in the efficiency of silver transport. It should be noted that the presence of various acids (e.g. $\mathrm{HNO}_{3}$ ) in the acceptor phase not only decrease the efficiency of transport but also leads to bleeding the carrier from the membrane phase into the aqueous phases.

Table 1. Effect of the nature of stripping agent in the acceptor phase on silver transport

\begin{tabular}{lcc}
\hline $\begin{array}{l}\text { Stripping agent } \\
\left(\mathrm{mol} \mathrm{L}^{-1}\right)\end{array}$ & $\begin{array}{c}\text { transported into } \\
\text { acceptor phase/(\%) }\end{array}$ & $\begin{array}{c}\text { remaining in } \\
\text { donor phase/(\%) }\end{array}$ \\
\hline $\mathrm{HNO}_{3}(0.1)$ & 8.47 & 79.97 \\
$\mathrm{Na}_{2} \mathrm{~S}_{2} \mathrm{O}_{3}(0.1)$ & 1.66 & 34.44 \\
$\mathrm{Na}_{2} \mathrm{~S}_{2} \mathrm{O}_{3}(0.2)$ & 33.17 & 10.08 \\
$\mathrm{Na}_{2} \mathrm{~S}_{2} \mathrm{O}_{3}(0.5)$ & 63.80 & 9.14 \\
$\mathrm{Na}_{2} \mathrm{SO}_{3}(0.1)$ & 4.27 & 21.34 \\
$\mathrm{NH}_{3}(0.1)$ & 78.67 & 16.46 \\
$\mathrm{NaI}_{2}(0.5)$ & 64.13 & 42.54 \\
$\mathrm{KSCN}(0.1)$ & 99.32 & 0.56
\end{tabular}

Donor: $5 \mathrm{~mL}$ of $1 \times 10^{-4} \mathrm{~mol} \mathrm{~L}^{-1} \mathrm{Ag}^{+}$; membrane, $20 \mathrm{~mL}$ of $5 \times 10^{-4} \mathrm{~mol} \mathrm{~L}^{-1} \mathrm{MLC}$ acceptor, $10 \mathrm{~mL}$ of different stripping agent with various concentration.

The maximum concentration of potassium thiocyanate in the acceptor phase was investigated and found to be in the $0.1-0.5 \mathrm{~mol} \mathrm{~L}^{-1}$ range (Figure $5 \mathrm{~B}$ ). It is interesting to note that the absence of a metal ion receptor in the acceptor 
phase resulted in no measurable silver transport even for much longer time periods.

The influence of the $\mathrm{pH}$ of the donor phase on the efficiency of $\mathrm{Ag}^{+}$was studied in the 2.0 to $10.0 \mathrm{pH}$ range, adjusted by nitric acid or $\mathrm{NaOH}$ and the results are shown in Figure 5C. As it can be seen, in highly acidic pH the efficiency of silver transport decreased sharply, most probably due to the interference of $\mathrm{H}_{3} \mathrm{O}^{+}$on MLC and as result diminishes the complexation strength. On the other hand, in highly alkaline media, significant amount of MLC was quickly migrated to aqueous donor phases, so that the efficiency of silver transport decreased. Thus, maximum silver transport occurs in the $\mathrm{pH}$ 5.0-8.0. The effect of $\mathrm{pH}$ of the acceptor phase was also investigated and the $\mathrm{pH} 7$ was selected as optimum value for both aqueous phases.

As an additional experiments the above optimization processes was performed on two other concentrations of silver ion. The optimum conditions with respect to $\mathrm{SCN}^{-}$ concentration in the acceptor phase and MLC in the membrane obtained for transport of $1 \times 10^{-3}$ and $5 \times 10^{-5} \mathrm{~mol}$ $\mathrm{L}^{-1}$ silver were similar to the optimum concentrations for the transport of the $1 \times 10^{-4} \mathrm{~mol} \mathrm{~L}^{-1}$ silver (i.e. $0.1 \mathrm{~mol} \mathrm{~L}^{-1}$

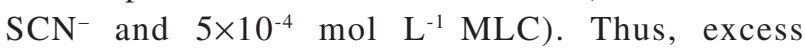
concentrations of $\mathrm{SCN}^{-}$and MLC do not affect the efficiency of transport experiments.

Figure 6 shows the time dependence of $\mathrm{Ag}^{+}$transport through the liquid membrane under the optimum experimental conditions. It is clear that the extraction of silver from the aqueous donor phase into the organic membrane occurs very rapidly, so that extraction seems to be almost complete after approximately $50 \mathrm{~min}$. However, the release of $\mathrm{Ag}^{+}$into aqueous acceptor phase occurs at a slower rate. It was confirmed that about $96 \%$ of silver ion was transported from the donor phase into the acceptor phase after 120 min under optimal conditions. The reproducibility of silver transport was investigated and the percent of metal ion transported after $120 \mathrm{~min}$ as obtained from 5 replicate measurements was found to be $97.8 \pm 1.0$.

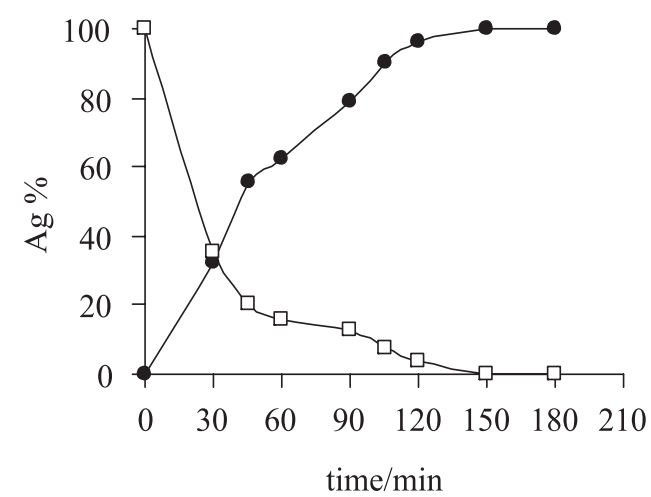

Figure 6. Time dependence of silver transport: $(\bullet)$ transported; $(\square)$ remaining. Conditions similar to those mentioned in Table 2.
To find the reproducibility of the transport system under investigation, the experiment was repeated five times under the optimum conditions of transport for 120 minutes. The results of these experiments are illustrated in Table 2. A relative error of $1.20 \%$ was obtained from the resulting data.

Table 2. Transport reproducibility

\begin{tabular}{lcc}
\hline Run & $\begin{array}{c}\text { transported into } \\
\text { acceptor phase/(\%) }\end{array}$ & $\begin{array}{c}\text { remaining in } \\
\text { donor phase/(\%) }\end{array}$ \\
\hline 1 & 99.32 & 0.56 \\
2 & 97.36 & 1.12 \\
3 & 96.12 & 3.58 \\
4 & 97.72 & 1.53 \\
5 & 98.53 & 0.77 \\
& 97.81 mean value & \\
& $1.00 \mathrm{SD}$ & \\
& $1.20 \mathrm{RSD}$ & \\
\hline
\end{tabular}

Donor phase: $5 \mathrm{~mL}$ of $1 \times 10^{-4} \mathrm{~mol} \mathrm{~L}^{-1} \mathrm{Ag}^{+}$; membrane phase, $20 \mathrm{~mL}$ of $5 \times 10^{-4} \mathrm{~mol} \mathrm{~L}^{-1} \mathrm{MLC}$; Acceptor phase, $10 \mathrm{~mL}$ of $\mathrm{KSCN}\left(0.1 \mathrm{~mol} \mathrm{~L}^{-1}\right)$; time of transport, $120 \mathrm{~min}$.

In order to study the selectivity of the membrane system for the silver ions, the percentage transport of $\mathrm{Ag}^{+}$ and $\mathrm{M}^{\mathrm{n}+}$ cations, which were present with silver ion in equimolar concentration, into acceptor phase was determined. The obtained results are listed in Table 3. As it can be seen, among a wide variety of cation studied, only $\mathrm{Cr}^{3+}$ and $\mathrm{Pb}^{2+}$ ions have shown some potential

Table 3. Amount of cation transported from various mixtures through membrane

\begin{tabular}{ccc}
\hline Cation & $\begin{array}{c}\text { Transported into } \\
\text { acceptor phase } /(\%)\end{array}$ & $\begin{array}{c}\text { Remaining in } \\
\text { donor phase/(\%) }\end{array}$ \\
\hline
\end{tabular}

Mixture 1

$\begin{array}{ccc}\mathrm{Ag}^{+} & 97.72 & 0.00 \\ \mathrm{Zn}^{2+} & 0.93 & 97.21 \\ \mathrm{Cd}^{2+} & 1.97 & 98.22 \\ \mathrm{Ni}^{2+} & 0.00 & 94.60 \\ \mathrm{Co}^{2+} & 0.00 & 96.84 \\ \mathrm{Mn}^{2+} & 0.00 & 100\end{array}$

Mixture 2

\begin{tabular}{|c|c|c|c|}
\hline & $\mathrm{Ag}^{+}$ & 51.25 & 48.75 \\
\hline & $\mathrm{Cr}^{3+}$ & 61.45 & 38.46 \\
\hline & $\mathrm{Cu}^{2+}$ & 0.00 & 11.18 \\
\hline & $\mathrm{Pb}^{2+}$ & 0.00 & 59.68 \\
\hline & $\mathrm{Ca}^{2+}$ & 24.36 & 63.95 \\
\hline & $\mathrm{Mg}^{2+}$ & 0.00 & 100 \\
\hline \multicolumn{4}{|l|}{ Mixture $3 *$} \\
\hline & $\mathrm{Ag}^{+}$ & 95.18 & 0.00 \\
\hline & $\mathrm{Cr}^{3+}$ & 13.61 & 86.39 \\
\hline & $\mathrm{Cu}^{2+}$ & 0.00 & 100 \\
\hline & $\mathrm{Pb}^{2+}$ & 9.39 & 90.61 \\
\hline & $\mathrm{Ca}^{2+}$ & 0.00 & 100 \\
\hline & $\mathrm{Mg}^{2+}$ & 0.00 & 100 \\
\hline
\end{tabular}


interfering effect. The interference of these cations can be diminished in the presence of EDTA $\left(1 \times 10^{-3} \mathrm{~mol} \mathrm{~L}^{-1}\right.$ at $\mathrm{pH}$ 6) as a masking agent in the donor phase. It is interesting to note that, under optimal experimental conditions, the $\mathrm{Mn}^{+}$cations used revealed no measurable interfering effect even when an excess molar ratio of $\mathrm{Mn}^{+} /$ $\mathrm{Ag}^{+} \geq 500$ was employed. Also, the mercury(II) ions showed no interference in the transport of silver ions, most probably due to precipitation of $\mathrm{Hg}^{2+}$ ions at $\mathrm{pH} 6$.

\section{Conclusions}

Transport of silver ions through a chloroform-MLC bulk liquid membrane was studied. The mechanism of transport was discussed. The optimum conditions of transport were found at $\mathrm{pH} 7$ in the feed solution, $5 \times 10^{-4}$ mol L ${ }^{-1}$ MLC in the liquid membrane, and $0.1 \mathrm{~mol} \mathrm{~L}^{-1}$ $\mathrm{KSCN}$ in the stripping solution. The simplicity, excellent efficiency and high selectivity for $\mathrm{Ag}^{+}$ion transport shown by the membrane system demonstrate its potential applicability to the selective separation, concentration, or purification of silver from mixtures.

\section{Acknowledgments}

Financial support from the Research Affairs of Urmia University is acknowledged. The authors are grateful to Prof. Sacide Altionoz for the supply of pure Meloxicam.

\section{References}

1. Jonsson, J. A; Matiasson, L.; TrAC 1992, 11, 106.

2. Safavi, A.; Shams, E.; Talanta 1999, 48, 1167.

3. Chaudry, M. A.; Amin, S.; Malik, M. T.; Sep. Sci. Technol. 1996, 31, 1309.

4 . Sirlin, C.; Burgard, M.; Leroy, M. J. F.; J. Membr. Sci. 1990, 54, 299.

5. Kuo, Y.; Gregor, H. P.; Sep. Sci. Technol. 1983, 18, 421.

6. Audunsson, G.; Anal. Chem. 1986, 58, 2714.
7. Moldovan, M.; Milagros GoNmez., M.; Antonia Palacios, M.; Anal. Chim. Acta 2003, 478, 209.

8. Koh, T.; Sugimoto, T.; Anal. Chim. Acta 1996, 333, 197.

9. Ohmiya, Y.; Dung, N. T. K.; Sekine, T.; Bull. Chem. Soc. Jpn. 1997, 53, 1167.

10. Kolthoff, I. M.; Chantooni, M. K.; J. Chem. Eng. Data 1993, $38,556$.

11. Saito K.; Murakami, S.; Muromatsu, A.; Sekido, E.; Polyhedron 1993, 12, 1587.

12. Sekido, E.; Chayama, K.; Muroi, M.; Talanta 1985, 32, 1797.

13. Lamb, J. D.; Nazarenko, A. Y.; Uenishi, J.; Tsukube, H.; Anal. Chim. Acta 1998, 373, 167.

14. Saito, T.; Sep. Sci. Technol. 1998, 33, 855.

15. Lachowicz, E.; Talanta 1992, 39, 1031.

16. Shamsipur, M.; Akhond, M.; Bull. Chem. Soc. Jpn. 1997, 70, 339.

17. Ishikawa, J.; Sakamoto, H.; Otomo, M.; Analyst 1997, 122, 1383.

18. Izatt, R. M.; Lamb, J. D.; Bruening, R. L.; Wang, C.; Edge, N.; Bradshaw, J. S.; Sep. Sci. Technol. 1993, 28, 383.

19. Shamsipur, M.; Kazemi, S. Y.; Azimi, G.; Madaeni, S. S. ; Lippolis, V.; Garau, A.; Isaia, F.; J. Membr. Sci. 2003, 215, 87.

20. Lee, B. L.; Lee, Y. H.; Yoon, I.; Jung, J. H.; Park, K.; Lee, S. S.; Microchem. J. 2001, 68, 241.

21. Shamsipur, M.; Mashhadizadeh, M. H.; Sep. Purif. Technol. 2000, 20, 147.

22. Lachowicz, E.; Rozanska, B.; Teixidor, F.; Meliani, H.; Barboiu, M.; Hovnanian, N.; J. Membr. Sci. 2002, 210, 279.

23. Villamo, O.; Barboiu, C.; Barboiu, M.; Yan-Chun-Wan W.; Hovnanian, N.; J. Membr. Sci. 2002, 204, 97.

24. Yordanov, A. T.; Roundhill, D. M.; Coord. Chem. Rev. 1998, $170,93$.

25. Paiva, A. P.; Solvent Extr. Ion Exch. 2000, 18, 223.

26. Shamsipur, M.; Farhadi, K.; Sep. Sci. Technol. 2000, 32, 859.

27. Farhadi, K.; Teimouri, G.; Anal. Lett. 2004, 37, 1457.

28. Farhadi, K.; Teimouri, G.; Talanta 2005, 65, 925.

29. Kobuke, Y.; Hanji, K.; Horiguchi, K.; Asada, M.; Nakayama, Y.; Furukawa, J.; J. Am. Chem. Soc. 1976, 98, 7414.

Received: September 1, 2006

Web Release Date: May 3, 2007 